J. Asiat. Soc. Bangladesh, Sci. 42(1): 127-128, June 2016

--Short communication

\title{
NEW RECORD OF MONOCHAETIA KARSTENII VAR. GALLICA (STEY.) SUTTON ON BRASSICA NAPUS L. FROM BANGLADESH
}

\author{
SHAMIM SHAMSI ${ }^{1}$ AND SAROWAR HOSEN \\ Department of Botany, University of Dhaka, Dhaka-1000, Bangladesh
}

Ananamorphic fungus, namely Monochaetiakarstenii var. gallica (Stey.) Sutton has been recorded for the first time for Bangladesh. This is the first record of association of this species withanthracnose disease infected leaves of Brassica napus L.

Brassica napus L. is an annual or biennial herbaceous plant that belongs to the Brassicaceae family. It is known as mustard, rape, rapeseedand oilseed rape. B. napus is an important oilseed crop in the world. It is the second largest oil crop after soybean and occupies $13 \%$ seed oil production of the world. Its use has been documented in Europe since the 13th century and has been grown $2000 \mathrm{BC}$ in India mainly for its use as oil for lamps (Zafar et al. 2015). Its seed contain $40-50 \%$ oil and $36-40 \%$ protein in meal (Amin and Khalil 2005). Diseases play an important role in lowering rapeseed yield in the country. Rapeseed is attacked by more than 27 fungal diseases, of which alternaria black spot (Alternaria brassicicola), anthracnose (Colletotrichum gloeosporioides), black leg or stem canker (Leptosphaeria maculans), Cercospora leaf spot (Cercospora brassicicola), downy mildew (Peronospora parasitica), damping-off (Rhizoctina solani and Fusarium spp.), leaf blight (A.brassicae), leaf spot (Phyllosticta brassicae), sclerotinia stem rot (Sclerotinia sclerotiorum), Southern blight (Sclerotium rolfsii) are considered as major diseases. These diseases cause serious yield loss of mustard. Among these diseases anthracnose of leaf is one of the most serious diseases of B.napus L.

Anthracnose infected leaves of Brassica napus were collected from the Botanical Garden of Dhaka University and fungi were isolated from the samples following "Tissue plantingmethod" on PDA (Potato Dextrose Agar) medium (CAB 1968). Isolated fungi were identified based on morphological characteristics observed under acompound microscope following standard literatures (Ellis 1971, 1976, Sutton1 1982 and Barnett and Hunter 2000).

The isolated fungi were Alternaria sp., A. brassicicola, Colletotrichum gloeosporioides, Curvularia sp., Fusarium sp. and Monochaetia karstenii var. gallica (Stey.) Sutton.

Monochaetiakarstenii var. gallica (Stey.) Sutton, Can. J. Bot. 47: 2091 (1969) (Plate 1) Colonies white, cottony on PDA medium. Mycelia immersed, septate,

\footnotetext{
${ }^{1}$ Corresponding author, E-mail: prof.shamsi@gmail.com
} 
branched, pale brown to hyaline. Acervulus black, numerous, circular or linear. Dehiscence irregular. Conidiophores mostly cylindrical, straight, hyaline. Conidia mostly 4 euseptate, apical and basal cell hyaline, median cells brown, cell wall dark brown, smooth, continuous or constricted at the septa, 17-21 $\times 5-5.6 \mu \mathrm{m}$. Apical appendage $11-14 \mu \mathrm{m}$ long, basal appendage $1-3 \mu \mathrm{m}$ long.

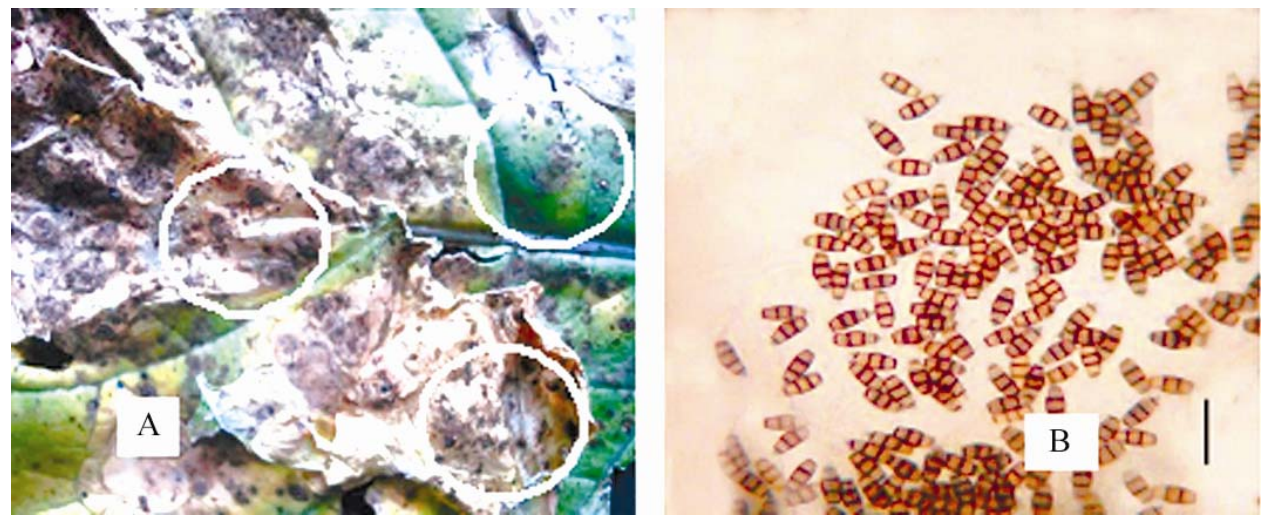

Plate 1. Brassica napus: A. Leaves showing anthracnose symptom with mycelial mat and acervuli. B. Conidiophores and conidia of Monochaetia karsteniivar. gallica within acervuli $(\mathrm{Bar}=$ $50 \mu \mathrm{m})$.

Specimen examined: On anthracnose infected leaves of Brassica napus L., Botanical Garden, University of Dhaka, S. Shamsi 3051, 15 February 2016.

Based on these morphological characteristics, the fungus was identified as Monochaetiakarstenii var. gallica. The fungus is new record for Bangladesh.

\section{References}

Amin, R. and S.K. Khalil. 2005. Effect of pre and post emergence herbicides and row spacing on Canola. Sarhad J. Agric. 21: 165-170.

Barnet, H.L. and B.B. Hunter. 1972. Illustrated Genera of Imperfecti Fungi. Burgess Publishing Company, U.S.A. Third Edition. pp. 241.

CAB (Commonwealth Agricultural Bureau), 1968. Plant Pathologist's Pocket Book. $1^{\text {st }}$ ed. The Commonwealth Mycological Institute, England. pp. 267.

Ellis, M.B. 1971. Dematiaceous Hyphomycetes. Commonwealth Mycological Institute, England. pp. 608.

Ellis, M.B. 1976. More Dematiaceous Hyphomycetes. Commonwealth Mycological Institute, England. pp. 507.

Sutton, B.C. 1980. The Coelomycetes, Fungi Imperfecti with Pycnidia Acervuli and Stromata. Commonwealth Mycological Institute, Kew, Surrey, England. pp. 696.

Zafar, F., F. A. Khan, T. Shahzadi, A. Ismail and Saif-ul-Malook. 2015. Origin, Importance, Establishment, Future Aspects and Strategies of Brassica napus L.American-Eurasian J. Agric. \& Environ. Sci., 15 (6): 978-984. 